\title{
Optimalisasi Hukum laut Nasional Untuk Pengembangan Potensi Sumber Daya Perikanan di Indonesia
}

\author{
Yosua Hamonangan Sihombing ${ }^{1}$
}

\begin{abstract}
Abstrak
Indonesia merupakan negara maritim yang memiliki potensi sumber daya perikanan yang sangat besar. Badan Pusat Statistik mencatat sektor perikanan berkembang 8,37\% pada kuartal ketiga tahun 2015 sehingga pengembangan potensi sumber daya perikanan menjadi bagian integral dari pembangunan nasional. Dalam pengembangannya, harus ada koordinasi antara Pemerintah Pusat dan Pemerintah Daerah sesuai dengan strategi pengembangan agar dapat dimanfaatkan bagi peningkatan perekonomian rakyat sekitar. Artikel ini akan menganalisis peran pemerintah dalam perlindungan dan pengelolaan sumber daya perikanan di laut Indonesia. Selanjutnya menganalisis penegakan hukum terhadap sumber daya perikanan di laut Indonesia. Adapun metode penulisan yang digunakan yaitu metode deskriptif analitis dengan menganalisis dan menjelaskan mengenai pelaksanaan pengaturan hukum laut nasional Indonesia dalam pengembangan potensi sumber daya perikanan. Dari analisis ini menjadi solusi yang diharapkan dapat diterapkan oleh pemerintah maupun instansi lainnya guna pengembangan potensi sumber daya perikanan dalam rangka peningkatan ekonomi nasional.
\end{abstract}

Kata Kunci : Sumber Daya Perikanan, Peningkatan Ekonomi Nasional, Hukum Laut.

\section{Abstract}

Indonesia is a maritime country has the potential of fisheries resources is very large. The Central Bureau of Statistics noted that developing the fisheries sector $8.37 \%$ in the third quarter of 2015 so that the development potential of the fishery resources become

1 Penulis adalah Staf Lembaga Konsultasi dan Bantuan Hukum Universitas 17 Agustus 1945 Jakarta 
an integral part of national development. In its development, there must be coordination between the Central Government and Local Government in accordance with the development strategy that can be utilized for the improvement of the people's economy around. This article will analyze the role of government in the protection and management of marine fishery resources in Indonesia. Further analyzes law enforcement on sea fishery resources in Indonesia. The writing method used is descriptive analysis method with analysis and explain the implementation of the national legal arrangements northwest Indonesia in developing the potential of fishery resources. From this analysis into a solution that is expected to be implemented by the government or other agencies in order to develop the potential of fishery resources in order to improve the national economy.

Keywords: Fisheries Resources, National Economic Improvement, Law of the Sea.

\section{Pendahuluan}

Indonesia adalah negara kepulauan yang terdiri dari pulau-pulau. Jumlah pulau-pulau yang dimiliki oleh Indonesia yaitu sebanyak 17.504 pulau. $^{2}$ Secara geopolitik, Indonesia memiliki peran yang sangat strategis karena berada di antara benua Asia dan Australia, serta diantara Samudera Pasifik dan Samudera Hindia. Hal itu menempatkan Indonesia sebagai poros maritim dunia dalam konteks perdagangan global (the global supply chain system) yang menghubungkan kawasan Asia Pasifik dengan Australia. ${ }^{3}$ Dengan strategisnya letak dan luasnya lautan yang dimiliki oleh Bangsa Indonesia, sumber daya laut Indonesia memiliki banyak potensi kekayaan laut yang dapat dimanfaatkan untuk kesejahteraan rakyat Indonesia.

Salah satu potensi kekayaan laut yang dapat dimanfaatkan dalam pengembangan perekonomian bangsa Indonesia yaitu sumber daya perikanan. Potensi lestari sumber daya perikanan laut Indonesia diperkirakan sebesar 7,3 juta ton per tahun yang tersebar di perairan wilayah Indonesia. ${ }^{4}$ Dari seluruh potensi sumber daya perikanan, jumlah tangkapan yang diperbolehkan (JTB) sebesar 5,8 juta ton per tahun atau sekitar $80 \%$ dari potensi lestari, dan baru dimanfaatkan

2 Badan Pusat Statistik, Luas Daerah dan Jumlah Pulau Menurut Provinsi, 2002-2014, www.bps. go.id diakses pada tanggal 12 November 2016.

3 Kementerian Kelautan dan Perikanan, Laporan Kinerja Satu Tahun Kementerian Kelautan dan Perikanan Tahun 2015, Jakarta: Kementerian Kelautan dan Perikanan, 2016, hlm. 12.

Ibid., hlm. 7. 
sebesar 5,4 juta ton atau baru 93\% dari JTB, sementara total produksi perikanan tangkap adalah 5,863 juta ton. ${ }^{5}$ Selain itu, laut Indonesia memiliki sekitar 8.500 species ikan yang menjadikan sumber daya perikanan di laut meliputi $37 \%$ dari species ikan di dunia dan beberapa jenis diantaranya mempunyai nilai ekonomis yang tinggi. ${ }^{6}$ Dengan demikian, sudah seharusnya potensi sumber daya perikanan yang tereksplorasi dan tereksploitasi menjadi penyokong kebutuhan pangan fungsional pada masa depan serta dapat meningkatkan perekonomian bangsa Indonesia.

Namun, pengembangan sektor sumber daya perikanan yang dilakukan pemerintah masih belum terlaksana secara maksimal. Hal itu dikarenakan dengan permasalahan perbatasan wilayah negara. Pengaturan praktek batas kelautan Negara Kesatuan Republik Indonesia yang diatur dalam ketentuan hukum laut Indonesia masih menemui kendala. Masalah rezim negara kepulauan ini mulai muncul pasca diberikannya kedaulatan dan hak berdaulatnnya suatu negara atas sumber daya alam yang dimilikinya terutama dalam sektor perikanan. Konvensi Perserikatan Bangsa-Bangsa tentang Hukum Laut 1982 (United Nations Covention on The Law of The Sea - UNCLOS) menyatakan bahwa negara pantai mempunyai hak mengelola segala sumber daya perikanan di laut teritorialnya sampai dengan zona ekonomi ekslusifnya. Akan tetapi, diberikannya hak untuk mengelola tersebut berdampak dengan maraknya penangkapan ikan secara ilegal yang terjadi di zona ekonomi ekslusif Indonesia maupun di laut teritorial Indonesia. ${ }^{7}$

IUU Fishing merupakan isu yang paling kompleks penanganannya dan dampak yang diakibatkannya berskala regional dan global, sehingga menjadi kegiatan prioritas dalam lingkup program pengawasan pemanfaatan sumber daya kelautan dan perikanan. Praktek-praktek IUU fishing yang terjadi di WPPNRI, baik oleh kapal-kapal perikanan Indonesia (KII) maupun oleh kapal-kapal perikanan asing (KIA) berpotensi menyebabkan kerugian yang sangat besar, dari aspek sosial, ekologi/lingkungan, maupun ekonomi. ${ }^{8}$ Kerugian negara akibat

$6 \quad$ Ibid.

7 Maria Maya Lestari, "Penegakan Hukum Pidana Perikanan di Indonesia Studi Kasus Pengadilan Negeri Medan", Jurnal Ilmu Hukum, Vol. 3 No. 2, 2014, hlm. 272.

8 Kementerian Kelautan dan Perikanan, Analisis Data Pokok Kementertian Kelautan dan Perikanan 2015, Jakarta: Pusat Data, Statistik, dan Informasi Kementerian Kelautan dan Perikanan, 2015, hlm. 134. 
dari IUU Fishing diperkirakan mencapai Rp. 11-17 trilliun dan estimasi kerugiaan negara-negara di dunia akibat IUU Fishing mencapai US\$ 10-23,5 milliar. ${ }^{9}$

Disamping kerugian tersebut, terdapat kerugian non material yang berdampak buruk akibat dari praktek IUU fishing, di antaranya: ${ }^{10}$

1. Hasil tangkapan yang tidak didaratkan di pelabuhan perikanan yang telah ditetapkan menyulitkan otoritas pengelolaan perikanan dalam menyediakan data yang akurat, yang sangat diperlukan untuk mengatur perijinan pemanfaatan sumber daya perikanan.

2. Beralihnya mata pencaharian nelayan kecil ke bidang usaha lain, termasuk kegiatan yang berpotensi melanggar peraturan perundang-undangan, seperti: menjadi penambang pasir timah liar, menjajakan jasa keahliannya melaut untuk mengangkut imigran gelap, memburu spesies ikan yang terancam punah karena adanya permintaan pasar dengan harga tinggi, dan lain sebagainya.

3. Hilangnya peluang kesempatan kerja bagi nelayan dalam negeri akibat penggunaan awak kapal berbendera asing (ABK), dan menurunnya kesempatan kerja pada industri pengelolaan ikan di dalam negeri akibat kekuarangan bahan baku.

Ancaman IUU Fishing juga dipicu dari kondisi sektor perikanan global, dimana beberapa negara mengalami penurunan stok ikan, pengurangan armada kapal penangkapan ikan akibat pembatasan pemberian izin penangkapan sedangkan permintaan produk perikanan makin meningkat. Di sisi lain, kemampuan pengawasan sumber daya kelautan dan perikanan di Indonesia belum memadai. ${ }^{11}$

Dari berbagai hal tersebut, Pokok permasalahan yang dicoba diulas dalam tulisan ini adalah : (a) bagaimana perlindungan potensi sumber daya perikanan di laut Indonesia? (b) bagaimana pengelolaan potensi sumber daya perikanan di laut Indonesia? dan (c) bagaimana penegakan hukum dalam pengelolaan sumber daya perikanan?

9 Kementerian Kelautan dan Perikanan, Laporan Kinerja Satu Tahun Kementerian Kelautan dan Perikanan Tahun 2014, Jakarta: Kementerian Kelautan dan Perikanan, 2015, hlm. 14.

10 Kementerian Kelautan dan Perikanan, op. cit., hlm. 134.

11 Kementerian Kelautan dan Perikanan, op. cit., hlm. 8. 


\section{Perlindungan Potensi Sumber Daya Perikanan di Laut Indonesia}

Perlindungan dan Pengelolaan ruang laut dan sumber daya kelautan di Indonesia tidak bisa dipisahkan dari sejarah panjang bangsa ini untuk memperjuangkan kedaulatan dan hak berdaulat di laut. Setidaknya tiga momen besar yang menjadi pilar dalam memperkukuh keberadaan Indonesia menjadi suatu negara yang merdeka dan negara yang didasarkan atas kepulauan sehingga diakui dunia. Hal tersebut didasarkan pada sumpah pemuda tanggal 28 Oktober 1928, proklamasi kemerdekaan Indonesia pada tanggal 17 Agustus 1945, dan Deklarasi Djuanda menjadi titik tolak perjuangan kedaultan Indonesia di laut. Deklarasi Djuanda menjadi langkah awal bagi Bangsa Indonesia untuk memperjuangkan kesatuan wilayah dan pengakuan secara de jure yang pada akhirnya diakui secara luas oleh komunitas internasional dan tertuang dalam Konvensi Perserikatan Bangsa-Bangsa tentang Hukum Laut 1982 (United Nations Covention on The Law of The Sea - UNCLOS). UNCLOS 1982 telah diratifikasi oleh Pemerintah Republik Indonesia melalui Undang-Undang No. 17 Tahun $1985^{12} \cdot{ }^{13}$

Pengaturan mengenai hukum laut tersebut menjadi acuan dalam mengatur sumber daya laut yang dimiliki oleh Bangsa Indonesia yang salah satunya yaitu sumber daya perikanan. Pengaturan mengenai sumber daya perikanan Indonesia diatur di dalam Undang-Undang Nomor 9 Tahun 1985 tentang Perikanan. Pada tahun 2004, Undang-Undang Nomor 9 Tahun 1985 diganti dengan UndangUndang Nomor 31 Tahun 2004 karena Undang-Undang yang lama belum menampung semua aspek pengelolaan sumber daya perikanan dan kurang mampu mengantisipasi perkembangan kebutuhan hukum serta perkembangan teknologi dalam rangka pengelolaan sumber daya perikanan. ${ }^{14}$

Selanjutnya pada tahun 2009, dilakukan perubahan Undang-Undang Nomor 31 Tahun 2004 menjadi Undang-Undang Nomor 45 Tahun 2009 tentang Perikanan.

12 Indonesia, Undang-Undang tentang Pengesahan United Nations Convention On The Law Of The Sea (Konvensi Perserikatan Bangsa-Bangsa Tentang Hukum Laut), UU No. 17 Tahun 1985, LN No. 76 Tahun 1985, TLN No. 3319.

13 Komisi Pemberantaran Korupsi, Laporan Hasil Kajian Sistem Pengelolaan Ruang Laut dan Sumber Daya Kelautan Tahun 2014, Jakarta: Kedeputian Bidang Pencegahan Direktorat Penelitian dan Pengembangan, 2014, hlm. 7.

14 Indonesia, Undang-Undang tentang Perikanan, UU No. 31 Tahun 2004, LN No. 118 Tahun 2004, TLN No. 4433, Konsideran huruf c. 
Hingga sampai saat sekarang, payung hukum tentang perikanan di Indonesia masih diatur dalam Undang-Undang Nomor 45 Tahun 2009. Dalam ketentuan tersebut, ada beberapa poin tentang ketentuan wajib untuk setiap orang yang melakukan usaha dan/atau kegiatan pengelolaan perikanan yaitu mengenai: ${ }^{15}$

a. Jenis, jumlah, dan ukuran alat penangkapan ikan;

b. Jenis, jumlah, ukuran dan penempatan alat bantu penangkapan ikan.

c. Daerah, jalur dan waktu atau musim penangkapan ikan.

d. Persyaratan atau standar prosedur operasional penangkapan ikan.

e. Sistem pemantauan kapal perikanan.

f. Jenis ikan baru yang akan dibudidayakan.

g. Jenis ikan dan wilayah penebaran kembali serta penangkapan ikan berbasis budi daya.

h. Pembudidayaan ikan dan perlindungannya.

i. Pencegahan pencemarandankerusakan sumber dayaikan sertalingkungannya.

j. Ukuran atau berat minimum jenis ikan yang boleh ditangkap.

k. Kawasan konservasi perairan.

1. Wabah dan wilayah wabah penyakit ikan.

m. Jenis ikan yang dilarang untuk diperdagangkan, dimasukkan, dan dikeluarkan ke dan dari wilayah Negara Republik Indonesia.

n. Jenis ikan yang dilindungi.

Di samping itu, dalam melakukan perlindungan sumber daya perikanan di wilayah laut Indonesia, mengenai usaha perikanan di bidang penangkapan, pembudidayaan, pengangkutan, pengolahan, dan pemasaran ikan di wilayah pengelelolaan perikanan Republik Indonesia wajib memiliki surat izin, beberapa bentuk perizinan tersebut yaitu:

a. Surat Izin Usaha Perikanan (SIUP), yaitu izin tertulis yang harus dimiliki perusahaan perikanan untuk melakukan usaha perikanan dengan sarana produksi yang tercantum dalam izin tersebut; ${ }^{16}$

15 Indonesia, Undang-Undang tentang Perubahan Atas Undang-Undang Nomor 31 Tahun 2009 tentang Perikanan, UU No. 45 Tahun 2009, LN No. 54 Tahun 2009, TLN No. 5073, Pasal 7 ayat (2).

16 Ibid., Pasal 1 angka 16 dan Pasal 26. 
b. Surat Izin Penangkapan Ikan (SIPI), yaitu izin tertulis yang harus dimiliki setiap kapal perikanan untuk melakukan penangkapan ikan yang merupakan bagian yang tidak terpisahkan dari SIUP; ${ }^{17}$

c. Surat Izin Kapal Pengangkutan Ikan (SIKPI), yaitu izin tertulis yang harus dimiliki setiap kapal perikananan untuk melakukan kapal pengangkutan; ${ }^{18}$

d. Surat Izin Berlayar, dipergunakan untuk setiap kapal perikanan yang akan berlayar dan pelabuhan perikanan. ${ }^{19}$

Ketentuan mengenai usaha perikanan di wilayah pengelolaan perikanan Republik Indonesia tidak hanya dilakukan oleh warga negara Republik Indonesia atau badan hukum Indonesia saja, namun diberikan juga kepada orang atau badan hukum asing yang melakukan usaha penangkapan ikan di Zona Ekonomi Ekslusif Indonesia (ZEEI) ${ }^{20}$ sepanjang hal tersebut menyangkut kewajiban Negara Republik Indonesia berdasarkan persetujuan internasional atau ketentuan hukum internasional yang berlaku. ${ }^{21}$ Beberapa bentuk perlindungan sumber daya perikanan di wilayah ZEEI, yaitu:

a. Pemberian surat izin usaha perikanan kepada orang dan/atau badan hukum asing yang beroperasi di ZEE Indonesia harus didahului dengan perjanjian perikanan, pengaturan akses, atau peraturan lainnya antara pemerintah Republik Indonesia dan pemerintah negara bendera kapal. Perjanjian perikanan tersebut harus mencantumkan kewajiban pemerintah negara bendera kapal untuk bertanggung jawab atas kepatuhan orang atau badan hukum negara bendera kapal untuk mematuhi perjanjian perikanan tersebut. ${ }^{22}$

17 Ibid., Pasal 1 angka 17 dan Pasal 27.

18 Ibid., Pasal 1 angka 18 dan Pasal 28.

19 Ibid., Pasal 42.

20 Zona Ekonomi Ekslusif (ZEE) atau Exclusive Economic Zone adalah suatu daerah di luar dan berdampingan dengan laut teritorial, yang tunduk rezim hukum khusus yang ditetapkan dalam Konfrensi Hukum Laut III. Hak-hak dan yurisdiksi negara pantai dan hak-hak serta kebebasan negara lain yang diatur dalam ketentuan-ketentuan konvensi, yang mana lebar ZEE tidak melebihi 200 mil laut dari garis pantai yang diukur dari lebar laut teritorial. Ketentuan batas maksimal mengenai lebar ZEE sejauh 200 mil laut ini mengisyaratkan tidak setiap negara pantai harus memiliki ZEE. Hanya negara yang memiliki wilayah laut lebih dari 24 mil laut yang memungkinkan memiliki ZEE, sepanjang tidak berbatasan langsung dengan pantai negara lain dengan jarak 24 mil laut tersebut. Lihat H. Syafrinaldi, Hukum Laut Internasional, (Pekanbaru: UIR Press, 2005), hlm. 19.

21 Indonesia, Undang-Undang tentang Perikanan, UU No. 31 Tahun 2004, loc. cit., Pasal 29.

22 Ibid., Pasal 30 ayat (1) dan (2). 
b. Pemerintah menetapkan pengaturan mengenai pemberian izin usaha perikanan kepada orang dan/atau badan hukum asing yang beroperasi di ZEE Indonesia, perjanjian perikanan, peraturan akses, atau pengaturan lainnya antara Pemerintah Republik Indonesia dan Pemerintah negara bendera kapal. ${ }^{23}$

c. Setiap kapal penangkapan ikan berbendera asing yang tidak memiliki izin penangkapan ikan selama berada di wilayah pengelolaan perikanan Republik Indonesia wajib menyimpan alat penangkapan ikan di dalam kapal. Lalu, kapal tersebut yang telah memiliki izin penangkapan ikan dengan satu jenis alat penangkapan ikan tertentu pada bagian tertentu di ZEE Indonesia dilarang membawa alat penangkapan ikan lainnya. ${ }^{24}$

d. Setiap orang yang memiliki dan/atau mengoperasikan kapal penangkap ikan berbendera asing yang digunakan untuk melakukan penangkapan ikan di ZEE Indonesia wajib memiliki izin, baik SIPI (Surat Izin Penangkapan Ikan) ${ }^{25}$ dan SIKPI (Surat Izin Kapal Pengangkutan Ikan)26.

e. Kapal perikanan berbendera asing yang melakukan penangkapan ikan di ZEE Indonesia wajib menggunakan anak buah kapal berkewarganegaraan Indonesia paling sedikit 70\% (tujuh puluh persen) dari jumlah anak buah kapal. ${ }^{27}$

\section{Pengelolaan Potensi Sumber Daya Perikanan di Laut Indonesia}

Pengelolaan potensi sumber daya perikanan yang dimiliki oleh Bangsa Indonesia harus dimanfaatkan sebagai potensi ekonomi bagi pembangunan nasional. Menurut Peraturan Menteri Kelautan dan Perikanan Nomor 18/ PERMEN-KP/2014 tentang Wilayah Pengelolaan Perikanan Republik Indonesia28, disebutkan bahwa Wilayah Pengelolaan Perikanan di Laut Indonesia dibagi menjadi

\footnotetext{
23 Indonesia, UU No. 45 Tahun 2009, loc. cit., Pasal 30 ayat (3).

24 Ibid., Pasal 38 ayat (1) dan (2).

25 Ibid., Pasal 27 ayat (2).

26 Ibid., Pasal 28 ayat (2).

27 Ibid., Pasal 35A.

28 Indonesia, Wilayah Pengelolaan Perikanan Negara Republik Indonesia, Peraturan Menteri Kementerian Kelautan dan Perikanan No. 18/PERMEN-KP/2014.
} 
11 Wilayah Pengelolaan Perikanan, yaitu (1) Selat Malaka dan Laut Andaman, (2) Samudera Hindia Sebelah Barat Sumatera dan Selat Sunda, (3) Samudera Hindia Sebelah Selatan Jawa Hingga Sebelah Selatan Nusa Tenggara, Laut Sawu dan Laut Timor Bagian Barat, (4) Selat Karimata, Laut Natuna, dan Laut China Selatan, (5) Laut Jawa, (6) Selat Makassar, Teluk Bone, Laut Flores, dan Laut Bali, (7) Teluk Tolo dan Laut Banda, (8) Teluk Tomini, Laut Maluku, Laut Halmahera, Laut Seram dan Teluk Berau, (9) Laut Sulawesi dan Sebelah Utara Pulau Halmahera, (10) Teluk Cendrawasih dan Samudera Pasifik dan (11) Teluk Aru, Laut Arafuru dan Laut Timor Bagian Timur. ${ }^{29}$

Di samping itu, dalam pengelolaan potensi sumber daya perikanan terdapat beberapa model berdasarkan UU No 31 Tahun 2004 tentang Perikanan yang telah dilaksanakan dan diupayakan oleh pemerintah untuk menjaga dan meningkatkan sumber daya perikanan yang berkelanjutan, antara lain:

a. Pengelolaan Perikanan Tangkap

Pengelolaan perikanan ini merupakan suatu sistem yang terdiri atas beberapa elemen atau subsistem yang saling berkaitan dan mempengaruhi satu dengan lainnya. Perikanan tangkap komersial sebagai suatu sistem yaitu sarana produksi, usaha penangkapan, prasarana (pelabuhan), unit pengolahan, unit pemasaran, dan unit pembinaan, Kesuluruhan sistem tersebut perlu dikelola secara terpadu. ${ }^{30}$ Menurut teori produksi, ada 4 tahapan produksi sumber daya alam dilihat dari jumlah penggunaan inputnya yaitu : (1) Tahap I, produksi yang dapat mencapai keuntungan ekonomi (profit) yang maksimum (Maximum Economic Yield) MEY, (2) Tahap II, produksi yang dapat mencapai jumlah produksi fisik yang maksimum (Maximum Sustainable Yield) MSY, (3) Tahap III, produksi yang tidak memperoleh untung atau rugi (break even point atau open acsess), (4) Tahap IV, produksi yang merugi. ${ }^{31}$ Terdapat beberapa

29 Kementerian Kelautan dan Perikanan, "Statistik Perikanan Tangkap Di Laut Menurut Wilayah Pengelolaan Perikanan Negara Republik Indonesia Tahun 2015-2014", Jakarta: Direktorat Jendral Perikanan Tangkap 2015, hlm. xx.

30 Komisi Pengawas Persaingan Usaha Republik Indonesia, Position Paper KPPU Tahun 2010 terkait "Kebijakan Klaster Perikanan Tangkap",hlm, 6, www.kppu.go.id, diakses pada tanggal 16 November 2016.

31 Indah Susilowati, “Keselarasan dalam Pemanfaatan dan Pengelolaan Sumberdaya Perikanan Bagi Manusia dan Lingkungan", (dalam Pidato Pengukuhan Guru Besar fakultas Ekonomi Universitas Diponegoro, Semarang. 8 Maret 2006), hlm. 16-17. 
argumentasi untuk menggeser kebijakan pengelolaan perikanan tangkap dalam rangka pemulihan stok sumber daya dan usaha perikanan tangkap, sebagai berikut: ${ }^{32}$

1) Pengeseran kebijakan perikanan, dari pengelolaan yang berorientasi pada perluasan usaha menuju pada pengelolaan yang berkelanjutan;

2) Pengelolaan perikanan memahami bahwa prinsip "sumber daya tidak pernah habis" sudah tidak berlaku atau dengan kata lain "perluasan usaha penagkapan yang tanpa kontrol tidak akan menguntungkan lagi";

3) Pengelola perikanan menyadari bahwa pemindahan usaha penangkapan dari wilayah yang mengalami tangkapan berlebih ke wilayah lainnya akan memberikan kontribusi terhadap kolapsnya perikanan tangkap setempat, dan;

4) Pergeseran pengelolaan dari ketergantungan terhadap model MSY menuju pengelolaan berdasarkan pendekatan ekosistem, dimana Kawasan Perlindungan Laut akan memainkan peran yang cukup penting.

b. Pengelolaan Sumberdaya Perikanan Berbasis Masyarakat (CBFM)

Pengelolaan Berbasis Masyarakat atau disebut Community Based Fisheries Management (CBFM) merupakan salah satu pendekatan pengelolaan sumberdaya alam misalnya perikanan, yang meletakkan pengetahuan dan kesadaran lingkungan masyarakat lokal sebagai dasar pengelolaannya. Pandangan ini tampaknya relevan untuk dilaksanakan di Indonesia dengan memperhatikan kondisi masyarakat dan kebudayaan serta unsur-unsur fisik masing-masing wilayah. ${ }^{33}$ Dalam sistem pengelolaan ini, masyarakat diberikan kesempatan dan tanggung jawab dalam melakukan pengelolaan terhadap sumber daya yang dimilikinya, dimana masyarakat sendiri mendefenisikannya sebagai suatu kebutuhan, tujuan dan aspirasinya serta masyarakat itu pula yang membuat keputusan demi kesejahteraannya. ${ }^{34}$

32 Indah Susilowati, "Menuju Pengelolaan Sumber Daya Perikanan Berkelanjutan yang Berbasis Pada Ekosistem: Studi Empiris di Karimunjawa, Jawa Tengah", Laporan Penelitian, Peneletian Hibah Kompetisi Tahun Anggaran Tahun 2012, 2012, hlm. 13.

33 Yudi Wahyudin, "Community Based Management (CBM) Pengelolaan Berbasis Masyarakat (PBM)", (makalah disampaikan pada Pelatihan Perencanaan dan Pengelolaan Wilayah Pesisir Terpadu (Integrated Coastal Zone Planning and Planing Management), Bogor, 15 September 2004), hlm. 2

34 Indah Susilowati, op. cit., hlm. 17. 
c. Pengelolaan Perikanan Berbasis Co-Management

Dalam konsep co-management, masyarakat lokal merupakan elemen penting yang bersama-sama dengan pemerintah dan stakeholders lainnya dalam pengelolaan sumber daya alam berupa gabungan dari dua pendekatan utama yaitu pengelolaan yang dilakukan oleh pemerintah (Goverment Centralized Management) dan pengelolaan yang dilakukan oleh masyarakat (Community Based Management). ${ }^{35}$

Prinsip co-management diwujudkan dalam bentuk penyerahan hak milik atas sumber daya perikanan kepada masyarakat. Pelaksanaan hak milik tersebut dibimbing oleh 4 (empat) prinsip, yaitu kesamaan, pemberdayaan, pelestarian, dan orientasi sistem. Karakteristik suatu perencanaan partisipatif adalah memberikan suatu dasar bagi keterlibatan itu dalam semua tahap proses perencanaan dari proses penyusunan hingga implementasinya. Komponen yang terdapat dalam pengelolaan ini antara lain hak pakai, hak pertukaran, hak pemerataan, dan skema pengelolaan dan wewenang. ${ }^{36}$

d. Pengelolaan Perikanan Berbasis Ekosistem (EFBM)

Pendekatan ecosystem based fisheries management (EBFM) untuk pengelolaan sumber daya perikanan merupakan salah satu metode alternatif untuk pengelolaan ekosistem sumber daya perikanan yang kompleks. The Ecosystem Principle Advisory Panel (EPAP), menyatakan bahwa EBFM mengemban sedikitnya 4 aspek utama yaitu (1) interaksi antara target spesies dengan predator, kompetitor dan spesies mangsa, (2) pengaruh musim dan cuaca terhadap biologi dan ekologi ikan, (3) interaksi antara ikan dan habitatnya, dan (4) pengaruh penangkapan ikan terhadap stok ikan dan habitatnya, khususnya bagaimana menangkap satu spesies yang mempunyai dampak terhadap spesies lain dalam ekosistem. ${ }^{37}$ Tujuan lain EBFM yaitu menjaga keutuhan dan kelestarian ekosistem.

Sebagai alat monitoring ekosistem, EBFM kemudian dilengkapi dengan indikator ekologi untuk mengukur perubahan ekosistem yang dimaksud.

35 Ibid., hlm. 19.

36 Ibid., hlm. 20.

37 Ibid., hlm. 21. 
Indikator-indikator ini diupayakan lebih berarti secara ekologi, mudah dipahami dan diterangkan di lapangan. Berdasarkan hasil monitoring ini diharapkan perubahan ekosistem termasuk manusia yang ada di dalamnya mudah dijelaskan, sehingga keadaan ekosistem secara keseluruhan akan diketahui dan tindakan perbaikan dapat dilakukan secepatnya untuk mengatasi kerusakan yang ada. Perencanaan dan pengelolaan laut berbasis ekosistem sangat relevan untuk strategi pembangunan berkelanjutan karena akan dapat menjain proses ekologi di laut, keanekaragaman biologi laut, dan kelangsungan hidup seluruh populasi spesies laut asli. ${ }^{38}$

Berdasarkan beberapa model pengelolaan perikanan yang dipaparkan di atas, formulasi kebijakan dalam pengelolaan perikanan di Indonesia dikembangkan dan dipadukan dalam Peraturan Menteri Kelautan dan Perikanan Nomor 9/ PERMEN-KP/2015 tentang Standar Kompetensi Kerja Khusus Pengelolaan Perikanan dengan Pendekatan Ekosistem. ${ }^{39}$ Pengelolaan perikanan dengan pendekatan ekosistem (Ecosystem Approach to Fisheries Management) selanjutnya disebut EAFM adalah sebuah pendekatan pengelolaan yang menitikberatkan pada pentingnya keterkaitan (konektivitas) antara sumberdaya perikanan dan kompenen ekosistem perairan termasuk aspek sosial, ekonomi dan kelembagaan. ${ }^{40}$ Pendekatan ini berusaha untuk menyeimbangkan tujuan sosial yang beragam, dengan memperhatikan pengetahuan dan ketidakpastian yang terdapat pada sumber daya biotik, abiotik dan manusia sebagai komponen ekosistem dan interaksi mereka dan menerapkan pendekatan yang terintegrasi untuk perikanan di dalam batas-batas ekologis yang berarti.

Dalam konteks ini, beberapa prinsip yang harus diperhatikan dalam implementasi EAFM antara lain adalah (1) perikanan harus dikelola pada batas yang memberikan dampak yang ditoleransi oleh ekosistem, (2) interaksi ekologis antar sumber daya perikanan dan ekosistem harus dijaga, (3) perangkat pengelolaan sebaiknya compatible untuk semua distribusi sumber daya perikanan, (4) prinsip kehati-hatian dalam proses pengambilan keputusan pengelolaan perikanan dan

38 Ibid.

39 Indonesia, Standar Kompetensi Kerja Khusus Pengelolaan Perikanan Dengan Pendekatan Ekosistem, Peraturan Menteri Kelautan dan Perikanan No. 9/PERMEN-KP/2015.

40 Ibid. 
(5) tata kelola perikanan mencakup kepentingan tata kelola perikanan mencakup kepentingan sistem ekologi dan sistem manusia. ${ }^{41}$

Implementasi EAFM memerlukan perangkat indikator yang dapat digunakan sebagai alat monitoring dan evaluasi mengenai sejauh mana pengelolaan perikanan sudah menerapkan prinsip-prinsip pengelolaan berbasis ekosistem. Dalam konteks manajemen perikanan, sebuah indikator dikatakan sebagai sebuah indikator yang baik apabila memenuhi beberapa unsur seperti: (1) menggambarkan daya dukung ekosistem; (2) relevan terhadap tujuan ko-manajemen, (3) mampu dimengerti oleh seluruh stakeholders; (4) dapat digunakan dalam kerangka monitoring da evaluasi; (5) long-term view; dan (5) mengambanrkan keterkaitan dalam sistem komanajemen perikanan. ${ }^{42}$

Kebijakan EAFM ditujukan kepada pengelolaan perikanan tangkap dan pengelolaan budidaya. Dalam pengelolaannya, produksi perikanan tangkap masih memegang peranan strategis dalam pembangunan perikanan Indonesia daripada produksi pengelolaan perikanan budidaya. ${ }^{43}$ Hal itu dikarenakan produksi perikanan tangkap memberikan sumbangsih nilai produksi yang besar dalam menunjang pertumbuhan perekonomian negara. Perbandingan produksi pengelolaan perikanan tangkap dan perikanan budidaya dapat terlihat dari data sebagai berikut: ${ }^{4}$

41 Kementerian Perikanan dan Kelautan, "Naskah Akademik Inisiasi Pengelolaan Perikanan Dengan Pendekatan Ekosistem (Ecosystem Approach to Fisheries Management) di Indonesia, Jakarta: Ditjen Perikanan Tangkap, 2014, hlm. 25.

42 Direktorat Sumber Daya Ikan - Direktorat Jenderal Perikanan Tangkap - Kementerian Kelautan dan Perikanan, WWF Indonesia, \& Pusat Kajian Sumber Daya Pesisir dan Lautan - Institut Pertanian Bogor, "Penentuan Insikator Pendekatan Ekosistem Dalam Pengelolaan Perikanan (Ecosysrem Approach to Fisheries Management)" (Disampaikan pada Lokakarya Nasional Penentuan Indikator Pendekatan Ekosistem Dalam Pengelolaan Perikanan (Ecosysrem Approach to Fisheries Management) di Wilayah Pengelolaan Perikanan Indonesia), Bogor, 22-24 September 2010, hlm. 8.

43 Kementerian PPN/Bappenas, "Kajian Strategi Pengelolaan Perikanan Berkelanjutan”, Jakarta: Direktorat Kelautan dan Periakan, Jakarta: Kementerian PPN/Bappenas, 2014, hlm. 5-1.

44 Sekretaris Jendral Kementerian Kelautan dan Perikanan, Program Prioritas 2016 dan Rencana Kerja 2017, (disampaikan oleh Pada Rapat Kerja Teknis Terpadu Tahun 2016, Jakarta, 30 Mei 2016), hlm. 6. 
Gambar 1

Produksi Perikanan Triwulan I Tahun 2015-2016

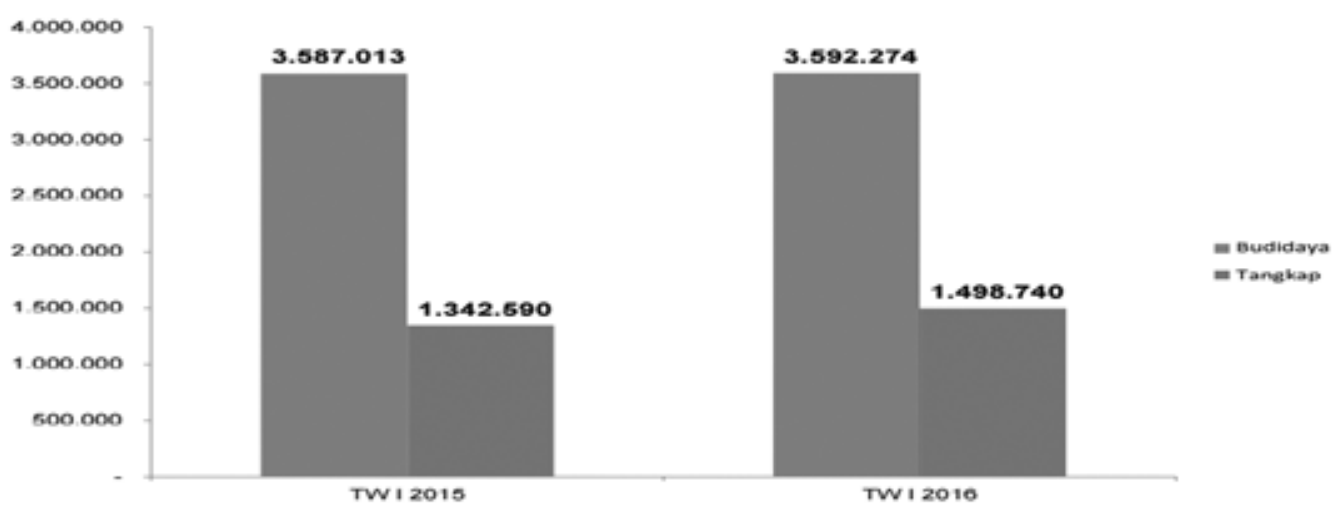

Sumber : Statistik Perikanan Tangkap dan Budidaya 2016.

Dari data diatas dinyatakan bahwa produksi perikanan tangkap pada triwulan I tahun 2016 mengalami pertumbuhan 11,63\% dibanding Triwulan I Tahun 2015. Begitu juga dengan produksi perikanan budidaya pada triwulan I tahun 2016 mengalami pertumbuhan 0,15\% dibanding triwulan I tahun 2015. ${ }^{45}$ Sehingga adanya pertumbuhan dalam pengelolaan sumber daya perikanan sudah seharusnya dapat dimanfaatkan sebagai salah satu komponen pendukung dalam peningkatan perekonomian nasional.

\section{Penegakan Hukum Laut Dalam Pengelolaan Sumber Daya Perikanan di Laut Indonesia}

Pengelolaan perikanan merupakan suatu kewajiban seperti yang telah diamanatkan oleh Undang-Undang No. 31 Tahun 2004 yang ditegaskan kembali pada perbaikan undang-undang tersebut pada Undang-Undang Nomor 45 Tahun 2009. Dalam konteks dasar hukum tersebut, pengelolaan perikanan didefenisikan sebagai semua upaya, termasuk proses yang terintegrasi dalam pengumpulan informasi, analisis, perencanaan, konsultasi, pembuatan keputusan, alokasi sumber daya ikan, dan implementasi serta penegakan hukum dari peraturan perundangundangan di bidang perikanan, yang dilakukan oleh pemerintah atau otoritas lain yang diarahkan untuk mencapai kelangsungan produktivitas sumber daya hati

45 Ibid. 
perairan dan tujuan yang telah disepakati dalam pengelolaan perikanan untuk kepetingan negara. ${ }^{46}$

Salah satu upaya dalam pengelolaan perikanan tersebut yaitu mengenai implementasi dan penegakan hukum dari peraturan perundang-undangan di bidang perikanan. Dalam pelaksanaannya, isu strategis dan permasalahan yang menjadi utama dalam mewujudkan pelaksanaan hukum kegiatan perikanan berkelanjutan di Indonesia yaitu mengenai pemberantasan perikanan illegal/ IUU fishing, akselerasi pertumbuhan ekonomi nasional melalui peningkatan hasil perikanan dan peningkatan kedaulatan pangan melalui peningkatan produksi perikanan. ${ }^{47}$

Penegakan hukum dalam pengelolaan sumber daya perikanan di wilayah laut Indonesia dilakukan terhadap tindakan IUU fishing di WPP-NRI. Beberapa bentuk tindakan IUU fishing yang dilakukan yaitu dengan cara penangkapan ikan tanpa izin, memiliki izin tetapi melanggar ketentuan sebagaimana ditetapkan oleh perundang-undangan yang berkaitan dengan perikanan, pemalsuan/manipulasi dokumen, transhipment ${ }^{48}$ di laut, tidak mengaktifkan transmitter $^{49}$, dan penangkapan ikan yang merusak dengan menggunakan bahan kimia, bahan biologis, bahan peledak, alat dan/atau cara, dan bangunan yang membahayakan melestarikan sumberdaya ikan. ${ }^{50}$

Sampai pada tahun 2015, penyimpangan yang marak terjadi terhadap pengelolaan sumber daya perikanan terdapat dalam izin-izin kapal yaitu SIPI dan

46 Kementerian Perikanan dan Kelautan, op. cit., hlm. 4.

47 Indonesia, Rencana Strategis Kementerian Kelautan dan Perikanan Tahun 2015-2019, Peraturan Menteri Kelautan dan Perikanan No. 25/PERMEN-KP/2015.

48 Alih Muatan (Transhipment) adalah pemindahan ikan hasil tangkapan dari kapal penangkapan ikan ke kapal pengangkut ikan atau pemindahan ikan hasil tangkapan dari kapan penangkap ikan ke kapal penangkap ikan. Dalam Indonesia, Usaha Perikanan Tangkap Di Wilayah Pengelolaan Perikanan Negara Republlik Indonesia, Peraturan Menteri Kelautan dan Perikanan No. PER.30/MEN/2012, Pasal 1 angka 34.

49 Transmitter adalah alat yang berfungsi untuk melakukan pemantauan kapal perikanan secara langsung, yang dipasang dan dioperasikan di atas kapal perikanan yang telah ditentukan serta digunakan untuk menerima/mengirimkan data posisi kapal perikanan ke pengelola sistem. Dalam Indonesia, Penyelenggaraan Sistem Pemantauan Kapal Perikanan, Peraturan Menteri Kelautan dan Perikanan No. PER. 05/MEN/2007, Pasal 1 angka 7.

50 Rohmin Dahuri, “Aspek Hukum Penanganan Tindak Pidana Perikanan”, Makalah Diklat Teknis Penanganan Tindak Pidana Perikanan Angkatan II, Pusdiklat Kejagung Republik Indonesia, 2013, hlm. 2. 
SIKPI. Dari hasil analisis dan evaluasi terhadap 1.132 kapal eks-asing, menunjukkan sebanyak 769 kapal melakukan pelanggaran berat dan 363 kapal melakukan pelanggaran ringan. Pelanggaran yang terjadi berupa: (1) menggunakan nahkoda dan anak buah kapal (ABK) berkewarganegaraan asing, (2) tidak mendaratkan ikan di pelabuhan pangkalan, (3) melakukan tindak pidana perdagangan orang dan perbudakan, (4) menggunakan BBM ilegal, (6) tidak mengaktifkan SPKP online, (7) menggunakan alat tangkap yang tidak sesuai dengan SIPI, (8) melakukan eksporimpor barang tanpa izin kepabeanan, (9) melakukan alih muatan ilegal ditengah laut, (10) tidak membangun/bermintra dengan Unit Pengelolaan Ikan (UPI).

Pemerintah telah melakukan serangkaian tindakan terhadap pelaku tindak pidana perikanan. Tindakan tersebut yaitu penenggelaman kapal ilegal yang terjadi sebanyak 113 kapal, pemeriksaan dilakukan pada 23.041 kapal, penyelesaian 198 kasus pelanggaran, pemulangan sebanyak 1.020 awak kapal berbendera asing atas kasus perbudakan di Benjina ke negara asal, pemulangan sebanyak 64 nelayan RI karena melakukan pelanggaran di negara lain dan penangkapan 157 unit kapal ilegal. $^{51}$

Penegakan hukum yang dilakukan oleh pemerintah melalui Kementerian Kelautan dan Perikanan dan aparat penegak hukum, dilaksanakan berdasarkan beberapa regulasi dalam mencegah dan memberantas tindak pidana perikanan yaitu :

a. Peraturan Menteri Kelautan dan Perikanan Nomor 42/PERMEN-KP/2016 tentang Perjanjian Kerja Laut Bagi Awak Kapal Perikanan;

b. Peraturan Menteri Kelautan dan Perikanan Nomor 71/PERMEN-KP/2016 tentang Jalur Penangkapan Ikan dan Penempatan Alat Penangkapan Ikan di Wilayah Pengelolaan Perikanan Negara Republik Indonesia;

c. Peraturan Menteri Kelautan dan Perikanan Nomor 4/PERMEN-KP/2015 tentang Larangan Penangkapan Ikan di Wilayah Pengelolaan Perikanan Negara Republik Indonesia 714;

d. Peraturan Menteri Kelautan dan Perikanan Nomor 42/PERMEN-KP/2015 tentang Sistem Pemantauan Kapal Perikanan;

51 Kementerian Kelautan dan Perikanan, loc. cit., hlm. 30. 
e. Peraturan Menteri Kelautan dan Perikanan Nomor 57/PERMEN-KP/2014 tentang Perubahan Kedua Atas Peraturan Menteri Kelautan dan Perikanan Nomor PER.30/MEN/2012 tentang Usaha Perikanan Tangkap Di Wilayah Pengelolaan Perikanan Negara Republik Indonesia;

f. Peraturan Menteri Kelautan dan Perikanan Nomor 56/PERMEN-KP/2014 tentang Penghentian Sementara (Moratorium) Perizinan Usaha Perikanan Tangkap Di Wilayah Pengelolaan Perikanan Negara Republik Indonesia.

Dalam konteks pertumbuhan dan peningkatan ekonomi, permasalahan dalam pembangunan perikanan tangkap mencakup berbagai kelemahan yang terdapat di internal sistem perikanan tangkap maupun berbagai ancaman yang berasal dari sistem perikanan tangkap di Indonesia. Menurut penulis, permasalahan tersebut dapat dikelompokkan menjadi permasalahan utama yaitu pengelolaan sumber daya ikan dan pembangunan sarana dan prasarana. ${ }^{52}$

Dalam hal pengelolaan sumber daya ikan, ketersediaan sumber daya ikan menjadi pilar utama dalam mewujudkan pembangunan perikanan tangkap secara optimal dan berkelanjutan, ketersediaan sumber daya ikan dipengaruhi faktor internal ikan khususnya terkait dengan kemampuan regenerasi ikan terhadap perubahan lingkungan baik akibat faktor alam maupun aktivitas manusia. Fakta empiris menunjukkan bahwa terjadinya degradasi sumber daya ikan sebagian besar akibat aktivitas manusia dalam mengeksploitasi sumber daya ikan yang melebihi batas kemampuannya (overfishing)..$^{53}$

Hal ini telah diindikasikan dengan tidak meratanya tingkat pemanfaatan sumber daya ikan di wilayah Indonesia. Dalam konteks perikanan tangkap, banyak perairan laut di kawasan barat dan tengah Indonesia sudah menunjukkan gejala padat tangkap (overfishing), seperti selat malaka, perairan timur sumatera, laut jawa dan selat bali. Sementara, diperairan laut kawasan timur Indonesia, tingkat pemanfaatan sumber daya ikan masih belum optimal (underfishing). Akibatnya, pada daerah-daerah penangkapan ikan tertentu yang mengalami over-exploited, nelayan-nelayannya umumnya menjadi miskin, karena sulit mendapatkan ikan hasil tangkapan. Disisi lain, pada daerah-daerah penangkapan ikan yang tingkat

52 Kementerian Kelautan dan Perikanan, “Rencana Strategis Tahun 2015-2019, Jakarta: Direktorat Jenderal Perikanan Tangkap, 2015, hlm. 31.

53 Ibid. 
pemanfaatannya adalah kapan-kapal perikanan illegal dari negara lain. ${ }^{54}$

Terhadap permasalahan mengenai overfishing, pengaturan yang telah dibentuk dan dilaksanakan oleh pemerintah melalui pengaturan mengenai pedoman penyusunan rencana pengelolaan perikanan di bidang penangkapan ikan. ${ }^{55}$ Dalam peraturan ini menyatakan tingkat pemanfaatan (eksploitasi) sumber daya ikan dikategorikan sebagai over-exploited, dilakukan pengurangan kegiatan penangkapan ikan dalam rangka mengembalikan kelestarian sumber daya ikan dan lingkungannya, melalui: (a) tidak memberikan perpanjangan Surat Izin Penangkapan Ikan (SIPI) yang telah habis masa berlakunya, dan/atau (b) pengurangan kapasitas alat penangkapan ikan dan alat bantu penangkapan ikan dalam rangka mengurangi ikan hasil tangkapan. ${ }^{56}$

Pengaturan hukum mengenai tindakan over-exploited dalam penangkapan ikan pada pengelolaan perikanan ternyata tidak disinkronisasikan dengan penetapan jangka waktu suatu wilayah pengelolaan perikanan yang dapat dilakukan tindakan penangkapan. Disamping pengaturan yang ada tidak memberikan perpanjangan SIPI dan pengurangan kapasitas alat penangkapan ikan serta alat bantu penangkapan ikan, seharusnya terhadap wilayah pengelolaan yang terjadi tindakan over-exploited diberikan jangka waktu pemulihan kembali ekosistem ikan yang telah habis tersebut. Dengan demikian, terdapat suatu kebutuhan akan keberadaan pengaturan hukum terhadap pengaturan mengenai jangka waktu dilakukannya penangkapan ikan di suatu wilayah pengelolaan perikanan dan pengaturan mengenai pemulihan kembali ekosistem wilayah pengelolaan perikanan tersebut.

Dalam konteks sarana dan prasana dalam pengelolaan sumber daya perikanan, pengembangan usaha perikanan tangkap akan optimal jika didukung dengan sarana dan prasarana yang mencakup kapal dan alat tangkap, pelabuhan perikanan beserta fasilitasnya, serta sarana dan prasana pendukung usaha penangkapan ikan lainnya. Permasalahan-permasalahan pokok terkait sarana dan prasarana dalam pengembangan sumber daya perikanan terdapat pada pelabuhan

54 Kementerian PPN/Bappenas, loc. cit., hlm. 6-1.

55 Indonesia, Pedoman Penyusunan Rencana Pengelolaan Perikanan Di Bidang Penangkapan Ikan, Peraturan Menteri Kelautan dan Perikanan Republik Indonesia No. PER.29/MEN/2012.

56 Ibid., Pasal 9. 
perikanan $^{57}$. Beberapa permasalahan tersebut antara lain: (1) sebaran pelabuhan perikanan yang tidak merata dan sebagai besar di Indonesia Bagian Barat, (2) pembangunan fasilitas pelabuhan perikanan belum lengkap sehingga masih ada pelabuhan perikanan yang belum dapat dimanfaatkan dengan baik, (3) Belum banyak pelabuhan perikanan yang dapat melakukan ekspor secara langsung, dan sebagainya..$^{58}$

Pelabuhan perikanan merupakan pendukung kegiatan pengelolaan dan pemanfaatan sumber daya ikan dan lingkungannya mulai dari praproduksi, produksi, pengolahan dan pemasaran. Dalam pelaksanaan, pelabuhan perikanan berfungsi sebagai fungsi pemerintahan dan fungsi pengusahaan. ${ }^{59}$ Pelabuhan sebagai fungsi pemerintahan yaitu melaksanakan pengaturan, pembinaan, pengendalian, pengawasan, serta keamanan dan keselamatan operasional kapal perikanan di pelabuhan perikanan. ${ }^{60}$ Fungsi pemerintahan tersebut meliputi $:^{61}$ (a) pelayanan pembinaan mutu dan pengelolaan hasil perikanan, (b) pengumpulan data tangkapan dan hasil perikanan, (c) tempat pelaksanaan penyuluhan dan pengembangan masyarakat nelayan, (d) pelaksanaan kegiatan operasional kapal perikanan, (e) tempat pelaksanaan pengawasan dan pengendalian sumber daya ikan, (f) pelaksanaan kesyahbandaran ${ }^{62}$, (g) tempat pelaksanaan fungsi karantina ikan, (h) publikasi hasil pelayanan sandar dan labuh kapal perikanan dan kapal pengawas kapal perikanan, (i) tempat publikasi hasil penelitian kelautan dan perikanan, (j) pemantauan wilayah pesisir, (k) pengendalian lingkungan, (l) kepabeanan, dan/atau (m) keimigrasian.

57 Pelabuhan perikanan adalah tempat yang terdiri atas darata dan perairan di sekotarnya dengan batas-batas tertentu sebagai tempat kegiatan pemerintahan dan kegiatan sistem bisnis perikanan yang digunakan sebagai tempat kapal perikanan bersandar, berlabuh, dan/ atau bongkar muat ikan yang dilengkapi dengan fasilitas keselamatan pelayaran dan kegiatan penunjang perikanan. Indonesia, Kepelabuhan Perikanan, Peraturan Menteri Kelautan dan Perikanan No. PER.08/MEN/2012, Pasal 1 angka 1.

58 Kementerian Kelautan dan Perikanan, loc. cit., hlm. 32-33.

59 Indonesia, Kepelabuhan Perikanan, op. cit., Pasal 3 angka 2.

60 Ibid., Pasal 3 angka 3.

61 Ibid., Pasal 3 angka 5.

62 Kesyahbandaran di pelabuhan perikanan adalah pelaksanaan tugas dan fungsi pemerintahan di pelabuhan perikanan untuk menjamis keamanan dan keselamatan operasional kapal perikanan. Ibid. Pasal 1 angka 12. 
Selain dari fungsi pemerintahan, pelabuhan perikanan juga berfungsi sebagai fungsi pengusahaan untuk melaksanakan pengusahaan berupa penyediaan dan/ atau pelayanan jasa kapal perikanan dan jasa terkait di pelabuhan perikanan. ${ }^{63}$ Fungsi pengusahaan juga meliputi $:^{64}$ (a) pelayanan tambat dan labuh kapal perikanan, (b) pelayanan bongkar muat ikan, (c) pelayanan pengelolahan hasil perikanan, (d) pemasaran dan distribusi ikan, (e) pemanfaatan fasilitas dan lahan di pelabuhan perikanan, (f) pelayanan perbaikan dan pemeliharaan kapal perikanan, (g) pelayanan logistik dan perbekalan kapal perikanan, (h) wisata bahari, dan/ atau (i) penyediaan dan/atau pelayanan jasa lainnya sesuai dengan peraturan perundang-undangan. Dengan berbagai fungsi tersebut, menjadikan pelabuhan perikanan sebagai salah satu hal yang vital dalam pengelolaan perikanan dan perkembangan perekonomian negara.

Ketersediaan pelabuhan perikanan di sentra-sentra usaha perikanan tangkap sangat vital untuk mendukung kelancaran usaha penangkapan ikan dan usaha pendukungnya. Sampai saat ini, jumlah pelabuhan perikanan di seluruh Indonesia sebanyak 1123 unit, terdiri dari 22 pelabuhan perikanan yang dikelola UPT Pusat, 84 pelabuhan perikanan yang dikelola UPTD Provinsi, 1130 pelabuhan perikanan yang dikelola UPTD Kabupaten/Kota, 15 pelabuhan perikanan yang dikelola oleh swasta dan 9 pelabuhan perikanan yang dikeloa oleh koperasi. Mengenai gambaran terhadap pelabuhan perikanan dapat dilihat dari data sebagai berikut. ${ }^{65}$

Tabel $1^{66}$

Jumlah Pelabuhan Perikanan

\begin{tabular}{|l|c|l|l|l|l|l|l|}
\hline \multirow{2}{*}{ Status Pelabuhan } & \multicolumn{7}{|c|}{ Kelas Pelabuhan } \\
\cline { 2 - 9 } & PP & PPI & PPI PUD & PPN & PPP & PPS & Jumlah \\
\hline Belum Operasional & - & 226 & 3 & - & - & - & 229 \\
\hline Operasional & 8 & 724 & 1 & 16 & 43 & 7 & 801 \\
\hline Tahap Konstruksi & - & - & - & - & - & - & - \\
\hline Tahap Perencanaan & - & 1 & 3 & - & - & - & 4 \\
\hline Tidak Operasional & - & 87 & - & 1 & 1 & - & 89 \\
\hline Total & $\mathbf{8}$ & $\mathbf{1 0 3 8}$ & $\mathbf{7}$ & $\mathbf{1 7}$ & $\mathbf{4 4}$ & $\mathbf{7}$ & $\mathbf{1 1 2 3}$ \\
\hline
\end{tabular}

Sumber : Pusat Informasi Pelabuhan Perikanan 2016.

63 Ibid., Pasal 3 angka 3.

64 Ibid., Pasal 3 angka 7.

65 Pusat Informasi Pelabuhan Perikanan, "Peta Pelabuhan PIPP", www.pipp.djpt.kkp.go.id, diakses pada tanggal 9 Maret 2017.

66 Ibid. 
Jumlah pelabuhan perikanan yang telah beroperasional mencapai 801 unit. Adapun sisanya, sebanyak 229 unit belum operasional, sebanyak 4 pelabuhan dalam tahap perencanaan dan 89 unit tidak operasional. Pelabuhan perikanan yang belum operasional (belum aktif) disebabkan fasilitas pelabuhan perikanan yang belum mencapai standar minimal operasional. Sedangkan pelabuhan perikanan yang tidak aktif karena masih dalam tahap rintisan pembangunan. ${ }^{67} \mathrm{Hal}$ ini menyebabkan pelabuhan perikanan itu belum dapat dimanfaatkan dengan baik untuk pengembangan sektor perikanan dalam peningkatan ekonomi nasional.

Dalam konteks melakukan ekspor hasil dari perikanan, pelabuhan perikanan yang digunakan yaitu pelabuhan perikanan kelas A yang disebut sebagai Pelabuhan Perikanan Samudera (PPS). ${ }^{68}$ Sampai pada saat ini, belum banyak pelabuhan perikanan yang dapat melakukan ekspor secara langsung. Tercatat ada 7 pelabuhan perikanan yang dikategorikan sebagai PPS yaitu (1) Pelabuhan Perikanan Kendari - Sulawesi Tenggara, (2) Pelabuhan Perikanan Bungus Sumatera Barat, (3) Pelabuhan Perikanan Nizam Zachman Jakarta - DKI Jakarta, (4) Pelabuhan Perikanan Cilacap - Jawa Tengah, (5) Pelabuhan Belawan - Sumatera Utara, (6) Pelabuhan Perikanan Bitung - Sulawesi Utara, dan (7) Pelabuhan Perikanan Lampulo - Aceh. ${ }^{69}$

Dari berbagai pelabuhan tersebut, pembangunan pelabuhan perikanan untuk melakukan ekspor hasil perikanan belum secara maksimal dilaksanakan diseluruh wilayah Indonesia. Idealnya setiap pulau di Indonesia seharusnya memiliki pelabuhan berskala internasional guna memudahkan distribusi logistik kelautan menuju luar negeri. ${ }^{70}$ Sejalan dengan hal tersebut, pemerintah mengeluarkan beberapa pengaturan mengenai pembagunan industri perikanan. Pengaturan tersebut yaitu melalui Permen KP No. 8 /PERMEN-KP/2016 tentang Rencana Kerja KKP tahun $2016^{71}$ dikuatkan dengan Inpres No. 7 Tahun 2016 tentang Percepatan Pembagunan Perikanan Nasional ${ }^{72}$ dan yang terbaru melalui Perpres

67 Ibid.

68 Indonesia, Kepelabuhan Perikanan, op. cit., Pasal 6.

69 Pusat Informasi Pelabuhan Perikanan, op. cit.

70 Republika, "Idealnya Tiap Pulau di Indonesia Punya Pelabuhan Internasional”, www.nasional.republika.co.id, diakses pada 9 Maret 2017.

71 Indonesia, Rencana Kerja Kementerian Kelautan dan Perikanan Tahun 2016, Peraturan Menteri Kelautan dan Perikanan Republik Indonesia No. PER.08/MEN/2016.

72 Indonesia, Percepatan Pembangunan Industri Perikanan Nasional, Instruksi Presiden Republik Indonesia No. 07 Tahun 2016. 
No. 3 Tahun 2017 tentang Rencana Aksi Percepatan Pembangunan Industri Perikanan Nasional ${ }^{73}$.

Namun, pengaturan secara khusus dalam percepatan pembangunan pelabuhan perikanan sampai saat ini belum ada. Seharusnya dalam pembangunan sektor perikanan juga menitikberatkan pada pembangunan pelabuhan sebagai sarana dan prasarana utama pendukung pengelolaan perikanan. Implementasi dari pembangunan perikanan tersebut dapat dilaksanakan dengan pembentukan pengaturan terkhusus mengenai percepatan pembangunan pelabuhan perikanan. Faktor lain yang menyebabkan pentingnya pembangunan pelabuhan perikanan, dikarenakan sektor perikanan menjadi salah satu sektor prioritas dalam ASEAN Economic Community. ${ }^{74}$ Dengan demikian, rumusan terhadap melahirkan pengaturan mengenai percepatan pembangunan pelabuhan perikanan berskala internasional harus dibentuk dan dilaksanakan agar dapat memudahkan dalam melakukan ekspor perikanan secara langsung dan bertujuan untuk peningkatan ekonomi nasional.

\section{Penutup}

Berdasarkan hasil penelitian yang telah dilakukan, maka pelaksanaan hukum dalam perlindungan, pengelolaan dan penegakan hukum merupakan suatu hal yang sangat penting dalam menciptakan suatu keadaan yang diinginkan suatu negara. Penegakan hukum terhadap perbuatan tindak pidana perikanan harus dilakukan sesuai dengan ketentuan dan proses hukum. Disamping penegakan hukum, pembentukan hukum dalam pengelolaan perikanan merupakan suatu keharusan dalam melaksanakan pengelolaan perikanan yang berkelanjutan. Pembentukan hukum tersebut dilaksanakan dengan pembentukan pengaturan

73 Indonesia, Rencana Aksi Percepatan Pembangunan Industri Perikanan Nasional, Peraturan Presiden Republik Indonesia No. 03 Tahun 2017.

74 Dalam cetak biru ASEAN Economic Community ditetapkan 12 sektor prioritas yang akan diintegrasikan. Tujuh diantaranya adalah sektor barang, yaitu isdustri agro, perikanan, industri berbasis karet, industri tekstil dan produk tekstil, industri kayu dan produk kayu, peralatan elektronik, dan otomotif. Sementara sisanya adalah lima sektor jasa, yakni transportasi udara, pelayanan kesehatan, pariwisata, logistik, serta industri teknologi informasi atau $e-A S E A N$. Dalam Kementerian Keuangan, "Laporan Dampak Asean Economic Community Terhadap Sektor Industri dan Jasa, serta Tenaga Kerja Di Indonesia Nomor LAP-10/K.F.4/2014", www.kemenkeu.go.id, diakses pada tanggal 9 Maret 2017. 
hukum terhadap pengaturan mengenai jangka waktu dilakukannya penangkapan ikan di suatu wilayah pengelolaan perikanan, pengaturan mengenai pemulihan kembali ekosistem wilayah pengelolaan perikanan tersebut dan pembangunan perikanan tersebut dapat dilaksanakan dengan pembentukan pengaturan terkhusus mengenai percepatan pembangunan pelabuhan perikanan. Dengan demikian, penegakan hukum dalam perlindungan dan pengelolaan sumber daya perikanan dapat dimaksimalkan dalam mewujudkan kedaulatan, keberlanjutan dan kesejahteraan serta meningkatkan perekonomian bangsa Indonesia ke depannya. 


\section{DAFTAR PUSTAKA}

Badan Pusat Statistik, Luas Daerah dan Jumlah Pulau Menurut Provinsi, 2002-2014, www.bps.go.id diakses pada tanggal 12 November 2016.

Dahuri, Rohmin. 2013. “Aspek Hukum Penanganan Tindak Pidana Perikanan”. Makalah Diklat Teknis Penanganan Tindak Pidana Perikanan Angkatan II, Pusdiklat Kejagung Republik Indonesia.

Direktorat Sumber Daya Ikan - Direktorat Jenderal Perikanan Tangkap - Kementerian Kelautan dan Perikanan, WWF Indonesia, \& Pusat Kajian Sumber Daya Pesisir dan Lautan - Institut Pertanian Bogor, "Penentuan Insikator Pendekatan Ekosistem Dalam Pengelolaan Perikanan (Ecosysrem Approach to Fisheries Management)". Disampaikan pada Lokakarya Nasional Penentuan Indikator Pendekatan Ekosistem Dalam Pengelolaan Perikanan (Ecosysrem Approach to Fisheries Management) di Wilayah Pengelolaan Perikanan Indonesia, Bogor, 22-24 September 2010.

Indonesia, Undang-Undang tentang Pengesahan United Nations Convention On The Law Of The Sea (Konvensi Perserikatan Bangsa-Bangsa Tentang Hukum Laut), UU No. 17 Tahun 1985, LN No. 76 Tahun 1985, TLN No. 3319.

Indonesia, Undang-Undang tentang Perikanan, UU No. 31 Tahun 2004, LN No. 118 Tahun 2004, TLN No. 4433.

Indonesia, Undang-Undang tentang Perikanan, UU No. 31 Tahun 2004, LN No. 118 Tahun 2004, TLN No. 4433, sebagaimana yang telah dirubah dengan Undang-Undang tentang Perikanan (Indonesia, Undang-Undang tentang Perubahan Atas Undang-Undang Nomor 31 Tahun 2004 tentang Perikanan, UU No. 45 Tahun 2009, LN No. 54 Tahun 2009, TLN No. 5073).

Indonesia, Rencana Aksi Percepatan Pembangunan Industri Perikanan Nasional, Peraturan Presiden No. 03 Tahun 2017.

Indonesia, Peraturan Menteri Kelautan dan Perikanan Republik Indonesia tentang Penyelenggaraan Sistem Pemantauan Kapal Perikanan, Peraturan Menteri Kelautan dan Perikanan No. PER. 05/MEN/2007. 
Indonesia, Kepelabuhan Perikanan, Peraturan Menteri Kelautan dan Perikanan No. PER.08/MEN/2012.

Indonesia, Pedoman Penyusunan Rencana Pengelolaan Perikanan Di Bidang Penangkapan Ikan, Peraturan Menteri Kelautan dan Perikanan No. PER.29/MEN/2012.

Indonesia, Peraturan Menteri Kelautan dan Perikanan Republik Indonesia tentang Usaha Perikanan Tangkap Di Wilayah Pengelolaan Perikanan Negara Republlik Indonesia, Peraturan Menteri Kelautan dan Perikanan Republik Indonesia No. PER.30/MEN/2012.

Indonesia, Peraturan Menteri Kelautan dan Perikanan Republik Indonesia tentang Wilayah Pengelolaan Perikanan Negara Republik Indonesia, Peraturan Menteri Kementerian Kelautan dan Perikanan No. 18/PERMEN-KP/2014.

Indonesia, Standar Kompetensi Kerja Khusus Pengelolaan Perikanan Dengan Pendekatan Ekosistem, Peraturan Menteri Kelautan dan Perikanan No. 9/PERMEN$\mathrm{KP} / 2015$.

Indonesia, Rencana Strategi Kementerian Kelautan dan Perikanan Tahun 2015-2019, Peraturan Menteri Kelautan dan Perikanan No. 25/PERMEN-KP/2015.

Indonesia, Rencana Kerja Kementrian Kelautan dan Perikanan Tahun 2016, Peraturan Menteri Kelautan dan Perikanan, No. PER.08/MEN/2016.

Indonesia, Percepatan Pembangunan Industri Perikanan Nasional, Instruksi Presiden No. 07 Tahun 2016.

Kementerian Kelautan dan Perikanan, 2015, "Statistik Perikanan Tangkap Di Laut Menurut Wilayah Pengelolaan Perikanan Negara Republik Indonesia Tahun 20152014", Jakarta: Direktorat Jenderal Perikanan Kementerian Kelautan dan Perikanan RI.

Kementerian Perikanan dan Kelautan, 2014, Naskah Akademik Inisiasi Pengelolaan Perikanan Dengan Pendekatan Ekosistem (Ecosystem Approach to Fisheries Management) di Indonesia, Jakarta: Ditjen Perikanan Tangkap.

Kementerian Kelautan dan Perikanan, 2015, Statistik Perikanan Tangkap Di Laut Menurut Wilayah Pengelolaan Perikanan Negara Republik Indonesia Tahun 20152014, Jakarta: Direktorat Jenderal Perikanan Tangkap. 
Kementerian Kelautan dan Perikanan, 2015, Laporan Kinerja Satu Tahun Kementerian Kelautan dan Perikanan Tahun 2014, Jakarta: Kementerian Kelautan dan Perikanan RI.

Kementerian Kelautan dan Perikanan, 2015, Rencana Strategis Tahun 2015-2019, Jakarta: Direktorat Jenderal Perikanan Tangkap.

Kementerian Kelautan dan Perikanan, 2015, Analisis Data Pokok Kementerian Kelautan dan Perikanan 2015, Jakarta: Pusat Data, Statistik, dan Informasi.

Kementerian Kelautan dan Perikanan, 2016, Laporan Kinerja Satu Tahun Kementerian Kelautan dan Perikanan Tahun 2015, Jakarta: Kementerian Kelautan dan Perikanan RI.

Kementerian Kelautan dan Perikanan, 2016, Sekretaris Jendral Kementerian Kelautan dan Perikanan, Program Prioritas 2016 dan Rencana Kerja 2017, disampaikan oleh Pada Rapat Kerja Teknis Terpadu Tahun 2016, Jakarta: Sekretaris Jenderal Kementerian Kelautan dan Perikanan RI.

Kementerian Keuangan, Laporan Dampak Asean Economic Community Terhadap Sektor Industri dan Jasa serta Tenaga Kerja Di Indonesia Nomor LAP-10/K.F.4/2014, diakses pada 9 Maret 2017 melalui www.kemenkeu.go.id.

Kementerian Kelautan dan Perikanan, 2016, Refleksi 2015 dan Outlook 2016 Pengawasan Sumber Daya Kelautan dan Perikanan, Jakarta: Direktorat Jenderal PSDKP Kementerian Kelautan dan Perikanan RI.

Kementerian PPN/Bappenas, 2014, "Kajian Strategi Pengelolaan Perikanan Berkelanjutan", Jakarta: Direktorat Kelautan dan Perikanan Kementerian PPN/Bappenas RI.

Komisi Pengawas Persaingan Usaha, 2010, Position Paper KPPU Terkait “Kebjakan Klaster Perikanan Tangkap", www.kppu.go.id, diakses pada 16 November 2016.

Lestari, Maria Maya. 2014. “Penegakan Hukum Pidana Perikanan di Indonesia Studi Kasus Pengadilan Negeri Medan", Jurnal Ilmu Hukum, Volume 3 No. 2.

Pusat Informasi Pelabuhan Perikanan, “Peta Pelabuhan PIPP, diakses pada 9 Maret 2017 melalui www.pjpp.djpt.kkp.go.id. 
Susilowati, Indah. 2006. “Keselarasan dalam Pemanfaatan dan Pengelolaan Sumberdaya Perikanan Bagi Manusia dan Lingkungan", dalam Pidato Pengukuhan Guru Besar fakultas Ekonomi Universitas Diponegoro, Semarang. 8 Maret 2006.

Susilowati, Indah. 2012. “Menuju Pengelolaan Sumber Daya Perikanan Berkelanjutan yang Berbasis Pada Ekosistem: Studi Empiris di Karimunjawa, Jawa Tengah", Laporan Penelitian, Peneletian Hibah Kompetisi Tahun Anggaran Tahun 2012.

Syafrinaldi, H. 2005. Hukum Laut Internasional, Pekanbaru: UIR Press.

Republika, “Idealnya Tiap Pulau di Indonesia Punya Pelabuhan Internasional, diakses pada 9 Maret 2017 melalui www.nasional.republika.co.id.

Wahyudin, Yudi. 2004. “Community Based Management (CBM) Pengelolaan Berbasis Masyarakat (PBM)", makalah disampaikan pada Pelatihan Perencanaan dan Pengelolaan Wilayah Pesisir Terpadu (Integrated Coastal Zone Planning and Planing Management), Bogor, 15 September 2004. 
